\title{
Pengaruh Faktor Kepuasan Kerja terhadap Kualitas Komunikasi Dokter- Pasien di Puskesmas Kota Cirebon
}

\section{The Influence of Job Satisfaction Factor on Physician-Patient Communication Quality at Puskesmas in Cirebon City}

\author{
Lintangkerty Suryanagari $^{1}$, Tri Pitara Mahanggoro ${ }^{2}$, Elsye Maria Rosa ${ }^{3}$ \\ Magister Administrasi Rumah Sakit, Universitas Muhammadiyah Yogyakarta \\ email: lintangksn@gmail.com, mastripitara@yahoo.com, elsye@umy.ac.id \\ Jl. Brawijaya, Geblagan, Tamantirto, Bantul, Daerah Istimewa Yogyakarta
}

\begin{abstract}
ABSTRAK
Kepuasan kerja merupakan salah satu satu bentuk kesejahteraan dokter. Kepuasan kerja dokter sebagai provider pelayanan kesehatan perlu menjadi perhatian agar meningkatkan kualitas pelayanan kesehatan. Komunikasi dokter-pasien merupakan salah satu bentuk pelayanan kesehatan dan dianggap sebagai hal utama dalam pelayanan kesehatan. Oleh karena itu, penelitian terkait faktor-faktor kepuasan kerja dokter terhadap kualitas komunikasi dokter-pasien bermanfaat untuk dilakukan. Jenis penelitian yang digunakan yaitu studi kuantitatif dengan model analisis jalur (path analysis) dengan strategi penelitian survei menggunakan kuesioner yang diisi oleh dokter dan pasien. Populasi merupakan seluruh dokter yang bekerja di puskesmas Kota Cirebon. Sampel penelitian dipilih memenuhi kriteria inklusi dan eksklusi. Jumlah sampel terdiri 44 dokter yang tersebar di 21 dari 22 puskesmas di Kota Cirebon dan 10 pasien per dokter sebagai responden. Analisis data menggunakan SPSS dan PLS-SEM. Penelitian ini menguji 5 faktor intrinsik kepuasan kerja, yaitu pencapaian, pekerjaan itu sendiri, pengakuan, tanggung jawab dan promosi serta pengembangan terhadap komunikasi dokter-pasien. Salah satu faktor kepuasan kerja dokter, yaitu pekerjaan itu sendiri (work itself) berpengaruh terhadap kualitas komunikasi dokter-pasien ( $p$-value 0,010). Pengaruh faktor-faktor ekstrinsik kepuasan kerja dokter terhadap komunikasi dokter-pasien disarankan untuk penelitian selanjutnya.
\end{abstract}

Kata kunci : Kepuasan Kerja, Komunikasi Dokter-Pasien, Kinerja, Motivasi

\begin{abstract}
Job satisfaction is a form of physician's welfare. Physician's job satisfaction as a health service provider needs to be a concern to improve the quality of health services. Physician-patient communication is considered as the essential thing in health services. Therefore, research related to the factors of physician's job satisfaction on physicianpatient communication quality is beneficial. The study used a quantitative method with a path analysis model using two questionnaires as survey research strategy that filled out by physicians and patients. The population is all physicians who work at puskesmas (public health center) in Cirebon City. The research sample was selected to meet the inclusion and exclusion criteria. The number of samples consisted of 44 physicians spread over 21 of 22 puskesmas in Cirebon City and 10 patients per physician as respondents. Data analysis using SPSS and PLS-SEM. This study examines 5 intrinsic factors of job satisfaction, there are achievement, work itself, recognition, responsibility and promotion as well as the advancement toward physician-patient communication quality. The work itself id the only factor is found to be affect physician-patient communication quality ( $p$-value 0.010). The effect of extrinsic factors of physician's job satisfaction on physician-patient communication is suggested for further research.
\end{abstract}

Keywords: Job Satisfaction, Physician-Patient Communication, Performance, Motivation 
Lintangkerty Suryanagari, Tri Pitara Mahanggoro, Elsye Maria Rosa : Pengaruh Faktor Kepuasan Kerja terhadap Kualitas ....

\section{PENDAHULUAN}

Upaya mencapai kesehatan yang baik merupakan isu sentral dalam pembangunan. Kesehatan yang baik memiliki potensi untuk meningkatkan produktivitas dan daya saing negara (World Health Organization \& van Lerberghe, 2008). Berdasarkan studi kualitatif oleh Mosadeghrad di Iran, didapatkan beberapa faktor yang mempengaruhi kualitas pelayanan kesehatan yang dibagi menjadi faktor terkait pasien, penyedia, organisasi dan lingkungan (Mosadeghrad, 2014). Berdasarkan pernyataan Mosadeghrad tersebut, dokter sebagai penyedia layanan kesehatan memegang peranan penting dalam kualitas pelayanan kesehatan. Oleh karena itu, kesejahteraan dokter perlu menjadi perhatian. Kesejahteraan dokter meliputi kepuasan kerja, kepuasan karir, kepuasan profesi, komitmen kerja dan keterlibatan (Scheepers dkk., 2015).

Tingkat kepuasan kerja tenaga kesehatan pada umumnya rendah. Kepuasan tenaga kesehatan di fasilitas pelayanan kesehatan publik di Etiopia, hanya 41,46\% (Deriba dkk., 2017). Studi di Amerika membandingkan profesi dokter dengan populasi pekerjaan lainnya. Hasil penelitian tersebut mengemukakan dokter memiliki kelelahan kerja (burnout) yang tinggi serta kepuasan kerja yang rendah (Shanafelt dkk., 2012). Kepuasan kerja dokter di Indonesia belum banyak dibahas dalam studi. Studi di Jawa Tengah, Indonesia, mendapatkan bahwa rata-rata tingkat kepuasan kerja dokter layanan primer berada di tingkat 3,19 dari 5. Dokter yang bekerja di praktek mandiri memiliki kepuasan yang lebih tinggi daripada bekerja di puskesmas rawat jalan maupun dengan rawat inap dan klinik (Maharani, 2019).

Kesejahteraan kerja dokter dapat memberi kontribusi positif terhadap kepuasan pasien, kepatuhan terhadap pengobatan, aspek interpersonal perawatan pasien dan kualitas keseluruhan proses perawatan (Scheepers dkk., 2015). Komunikasi dokter-pasien merupakan aspek interpersonal dalam perawatan pasien. Komunikasi dokter-pasien yang efektif dianggap sebagai inti pelayanan kesehatan dan merupakan fungsi sentral dalam membangun hubungan terapeutik dokter-pasien (Bensing dkk., 2013). Komunikasi efektif juga merupakan salah satu area kompetensi dokter dan bentuk kinerja professional dokter (Konsil Kedokteran Indonesia, 2012; van der Leeuw dkk., 2013). Studi lain mengemukakan bahwa kepuasan kerja dokter berpengaruh terhadap komunikasi-dokter pasien. Dokter yang mencapai kepuasan kerja yang tinggi berkomunikasi lebih baik pada aspek verbal maupun non-verbal (Bensing dkk., 2013). Berdasarkan studi tentang faktorfaktor yang mempengaruhi kepuasan kerja, diungkapkan bahwa terdapat faktor internal dan eksternal terkait kepuasan kerja. Faktor internal meningkatkan kepuasan kerja dokter 
sedangkan faktor eksternal lebih berperan dalam ketidakpuasan (Aziri, 2011). Berbeda dengan penelitian tersebut, penelitian lain mengungkap bahwa faktor motivasi yang tidak terkait dangan gaji hanya akan berpengaruh jika kebutuhan atas gaji terpenuhi (Chandler dkk., 2009). Berdasarkan pernyataan-pernyataan tersebut, studi ini mengkaji pengaruh faktor-faktor internal kepuasan kerja dokter yang lebih berperan dalam meningkatkan kepuasan kerja dokter dibandingkan faktor eksternal terhadap kualitas komunikasi dokter pasien di puskesmas, sehingga dapat memberikan manfaat terhadap upaya peningkatan kualitas pelayanan kesehatan.

\section{METODE}

Jenis penelitian yang digunakan yaitu studi kuantitatif dengan model analisis jalur (path analysis). Strategi penelitian yang digunakan melalui survei. Jenis dan rancangan penelitian ini dipilih untuk menguji hipotesis penelitian yang ingin mencari hubungan antara variabel bebas dan variabel terikat. Subyek penelitian ini adalah dokter umum yang bekerja di puskesmas di wilayah Kota Cirebon pada bulan November 2020 - Januari 2021. Obyek penelitian ini adalah seluruh puskesmas yang ada di Kota Cirebon. Satu puskesmas dieksklusi, karena kendala pengambilan data, sehingga hanya terdapat 21 dari 22 puskesmas yang terlibat dalam studi ini. Populasi penelitian ini terdiri dari seluruh dokter umum yang bekerja di puskesmas di Kota Cirebon. Teknik pengambilan sampel yang digunakan adalah simple random sampling. Jumlah sampel ditentukan berdasarkan tabel Isaac dan Michael (HR, 2019). Berdasarkan tabel tersebut, dari jumlah populasi 49 dokter dengan tingkat error 5\%. Kriteria inklusi yang digunakan pada penelitian ini yaitu dokter yang bekerja sebagai fungsional, berstatus PNS dan telah bekerja di puskesmas selama minimal 6 bulan merujuk pada penelitian sebelumnya tentang kepuasan kerja dokter (Sharma dkk., 2014), sedangkan kriteria eksklusi pada penelitian ini yaitu dokter umum yang hanya berperan sebagai struktural. Responden untuk menilai kualitas komunikasi dokter pasien berjumlah 10 pasien/dokter.

Instrumen penelitian ini menggunakan kuesioner baik untuk menilai variabel bebas maupun terikat. Kuesioner kepuasan kerja dokter digunakan untuk menilai variabel-variabel bebas pada penelitian ini. Kuesioner tersebut berbentuk kuesioner tertutup, terdiri dari berbagai pertanyaan yang disadur dari berbagai penelitian sebelumnnya tentang kepuasan kerja (Bhatnagar \& Srivastava, 2012; Giese \& Avoseh, 2018; Sharma dkk., 2014; Van Ham dkk., 2006). Komunikasi dokter-pasien sebagai variabel terikat dinilai berdasarkan kuesioner "Komunikasi Efektif Dokter-Pasien” yang 
Lintangkerty Suryanagari, Tri Pitara Mahanggoro, Elsye Maria Rosa : Pengaruh Faktor Kepuasan Kerja terhadap Kualitas ....

diisi oleh pasien. Kuesioner ini disadur dari Communication Assessment Tool yang telah disesuaikan dengan praktek klinis, terdiri dari 14 item pertanyaan (Makoul dkk., 2007). Sebelum digunakan dalam penelitian, kuesioner dilakukan uji validitas dan reliabilitas. Berdasarkan uji validitas dan reliabilitas dengan SPSS menunjukkan bahwa semua indikator pada variabel komunikasi dokter ini valid dan semua indikator pada kuesioner komunikasi dokter-pasien valid. Selanjutnya, dilakukan olah data statistik deskriptif menggunakan SPSS dan pengujian hipotesis dilakukan PLS-SEM.

\section{HASIL}

Karakteristik responden dalam penelitian ini dapat dilihat pada tabel 1 dan tabel 2. Usia dokter umum berstatus PNS tersebut umumnya berusia 26-35 tahun sejumlah 21 orang $(37,7 \%)$ dengan prosentase jenis kelamin secara keseluruhan 20,5\% laki-laki dan $79,5 \%$ perempuan. Jumlah dokter umum paling banyak bekerja $\leq 10$ tahun $(52,3 \%), 20$ orang bekerja 11-20 tahun, sedangkan 1 orang lainnya telah bekerja selama 30 tahun.

Tabel 1. Distribusi Karakteristik Responden Dokter Umum di Puskesmas Kota Cirebon

\begin{tabular}{llll}
\hline Karakteristik Responden & Frekuensi & Prosentase (\%) & p-Value \\
\hline Kecamatan & & & \\
Harjamukti & 11 & 25 & \\
Kejaksan & 8 & 18,2 & 0,094 \\
Kesambi & 11 & 25 & \\
Lemahwungkuk & 6 & 13,6 & \\
Pekalipan & 8 & 18,2 & \\
Usia $\quad$ & 1 & 23 & 0,110 \\
$\quad$ 25 tahun & 21 & 47,7 & \\
26-35 tahun & 12 & 27,3 & 0,482 \\
36-45 tahun & 10 & 22,7 & \\
46-55 tahun & & & \\
Jenis kelamin & 9 & 20,5 & 0,399 \\
Laki-laki & 35 & 79,5 & \\
Perempuan & & & \\
Lama kerja sebagai dokter PNS & 23 & 52,3 & \\
$\quad 10$ tahun & 20 & 45,5 & \\
11 - 20 tahun & 1 & 2,3 & \\
21-30 tahun & & &
\end{tabular}

Studi ini juga menganalisa karakteristik responden dokter umum terhadap kepuasan kerja dokter menggunakan chi-square. P-value didapatkan $>0,05$, bermakna karakteristik responden dalam penelitian ini tidak memiliki pengaruh signifikan terhadap kepuasan kerja dokter puskesmas di Kota Cirebon. 
Tabel 2. Distribusi Karakteristik Responden Pasien di Puskesmas Kota Cirebon

\begin{tabular}{lccc}
\hline \multicolumn{2}{c}{ Karakteristik Responden } & Frekuensi & Prosentase (\%) \\
\hline Usia & & & \\
& 21-20 tahun & 159 & 36,1 \\
31-40 tahun & 144 & 32,7 \\
& $41-50$ tahun & 99 & 22,5 \\
\multirow{3}{*}{ Jenis kelamin } & 51-60 tahun & 38 & 8,6 \\
& & & \\
& Laki-laki & 155 & 35,2 \\
& Perempuan & 285 & 64,8 \\
\hline
\end{tabular}

Selain melihat karakteristik responden uji statistik deskriptif juga menganalisis jawaban responden terhadap masing-masing indikator pengukur variabel. Penilaian responden di setiap indikator pada penelitian ini diukur dengan 'Ya' atau 'Tidak'. Sehingga nilai terbesar dari setiap indikator adalah 1 . Jika rata-rata hasil setiap indikator mendekati 1, maka dapat disimpulkan variabel tersebut sudah baik.

Hasil uji statistic variabel Kualitas Komunikasi Dokter-Pasien diperoleh bahwa secara keseluruhan rata-rata setiap indikator diatas 0,7 atau mendekati 1 sehingga dapat disimpulkan bahwa variabel Kualitas Komunikasi Dokter Pasien sudah baik. Keseluruhan rata-rata setiap indikator variabel pencapaian, pekerjaan itu sendiri, pengakuan, tanggung jawab dan promosi serta pengembangan pun mendekati 1, sehingga dapat disimpulkan bahwa kelima variabel tersebut sudah baik.

Metode Analisa data yang digunakan pada penelitian ini yaitu menggunakan PLS. Gambar 1 merupakan diagram jalur dalam penelitian ini. Desain diagram jalur (path model) terdiri dari konstruk atau variabel laten dan indikator. Variabel laten yaitu variabel yang tidak langsung diukur, yaitu faktor-faktor instrinsik kepuasan kerja dokter dan kualitas komunikasi dokter-pasien. Diagram jalur memperlihatkan model struktural (inner model) yaitu model yang menghubungkan antar variabel laten dan outer model yaitu model pengukuran yang menghubungkan indikator dengan variabel latennya. Arah panah pada path model berikut menggambarkan hubungan korelasi antara indikator dengan variabel laten dan korelasi antar variabel laten. 
Lintangkerty Suryanagari, Tri Pitara Mahanggoro, Elsye Maria Rosa : Pengaruh Faktor Kepuasan Kerja terhadap Kualitas ....

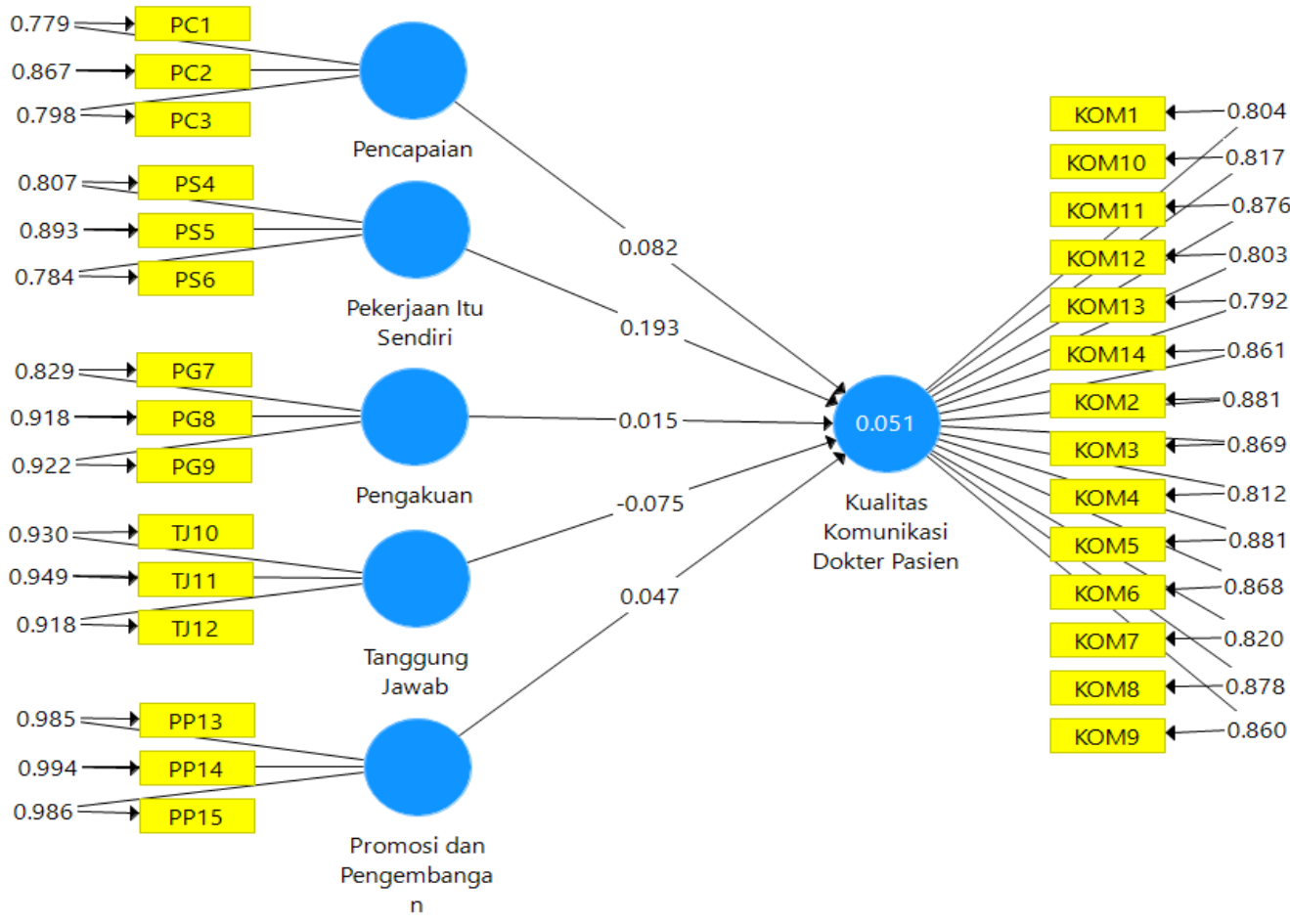

Gambar 1. Diagram Jalur

Pengujian outer model meliputi validitas konvergen dan validitas diskriminan.

Nilai outer model atau korelasi antara konstruk dengan variabel menunjukkan bahwa secara keseluruhan nilai loading factor lebih besar dari 0,7 , sehingga semua variabel valid dari model. Model juga dikatakan mempunyai discriminant validity yang cukup baik karena pada pengujian ini adalah nilai average variance extracted (AVE) pada semua variabel diperoleh sebagai hasil estimasi nilainya $>0,60$ sehingga dapat dinyatakan valid. Uji reliabilitas pada data juga telah dilakukan dan disimpulkan bahwa konstruk untuk semua variabel memenuhi kriteria reliabel. Hal ini ditunjukkan dengan nilai Cronbach's Alpha dan composite reliability yang diperoleh. Nilai yang hasilkan adalah $>0,70$ sesuai kriteria yang direkomendasikan dalam literatur.

Tabel 3. Nilai $R$ Square

\begin{tabular}{lc}
\hline Variabel & $R$ Square \\
\hline Kualitas Komunikasi Dokter Pasien & 0,051 \\
\hline
\end{tabular}

Nilai $R$-Square digunakan untuk menjelaskan pengaruh variabel laten eksogen tertentu terhadap variabel laten endogen substantif, yaitu kualitas komunikasi dokterpasien dalam penelitian ini (Ghozali \& Latan, 2015). Tabel 3 menunjukkan nilai R-square diperoleh sebesar 0,051. Hasil ini menunjukkan bahwa 5,1\% variabel Kualitas 
Komunikasi Dokter Pasien dijelaskan oleh variabel Pencapaian, Pekerjaan itu Sendiri, Pengakuan, Tanggung Jawab dan Promosi serta Pengembangan.

Tabel 4. Path Coefficient

\begin{tabular}{|c|c|c|c|c|c|}
\hline & $\begin{array}{l}\text { Original } \\
\text { Sample } \\
(\mathrm{O})\end{array}$ & $\begin{array}{c}\text { Sample } \\
\text { Mean } \\
\text { (M) }\end{array}$ & $\begin{array}{l}\text { Standard } \\
\text { Deviation } \\
\text { (STDEV) } \\
\end{array}$ & $\begin{array}{c}\text { T Statistics } \\
(|\mathrm{O} / \mathrm{STDEV}|)\end{array}$ & $\begin{array}{c}P \\
\text { Values }\end{array}$ \\
\hline $\begin{array}{l}\text { Pencapaian } \\
\text {-> Kualitas Komunikasi } \\
\text { Dokter Pasien }\end{array}$ & 0,082 & 0,092 & 0,071 & 1,159 & 0,247 \\
\hline $\begin{array}{l}\text { Pekerjaan itu Sendiri } \\
\text {-> Kualitas Komunikasi } \\
\text { Dokter Pasien }\end{array}$ & 0,193 & 0,204 & 0,075 & 2,585 & 0,010 \\
\hline $\begin{array}{l}\text { Pengakuan } \\
\text {-> Kualitas Komunikasi } \\
\text { Dokter Pasien }\end{array}$ & 0,015 & 0,008 & 0,064 & 0,239 & 0,811 \\
\hline $\begin{array}{l}\text { Tanggung Jawab } \\
\text {-> Kualitas Komunikasi } \\
\text { Dokter Pasien }\end{array}$ & $-0,075$ & $-0,067$ & 0,067 & 1,117 & 0,265 \\
\hline $\begin{array}{l}\text { Promosi dan } \\
\text { Pengembangan } \\
\text {-> Kualitas Komunikasi } \\
\text { Dokter Pasien }\end{array}$ & 0,047 & 0,053 & 0,053 & 0,889 & 0,374 \\
\hline
\end{tabular}

Berdasarkan tabel 4, hasil pengujian hipotesis pertama menunjukkan bahwa pengaruh variabel Pencapaian (X1) terhadap variabel Kualitas Komunikasi Dokter Pasien menunjukkan nilai estimasi sebesar 0,082 dan nilai signifikansi 0,247 lebih besar dari 0,05 sehingga dapat disimpulkan bahwa variabel Pencapaian tidak berpengaruh signifikan terhadap Kualitas Komunikasi Dokter Pasien yang berarti tidak sesuai dengan hipotesis $p$ ertama (hipotesis 1 ditolak).

Hasil pengujian hipotesis kedua menunjukkan bahwa variabel Pekerjaan itu sendiri (X2) terhadap variabel Kualitas Komunikasi Dokter Pasien menunjukkan nilai estimasi sebesar 0,193 dan nilai signifikansi 0,010 lebih kecil dari 0,05 sehingga dapat disimpulkan bahwa variabel Pekerjaan itu Sendiri berpengaruh signifikan terhadap Kualitas Komunikasi Dokter Pasien yang berarti sesuai dengan hipotesis kedua (hipotesis 2 diterima).

Pengujian hipotesis ketiga menunjukkan bahwa variabel Pengakuan terhadap variabel Kualitas Komunikasi Dokter Pasien menunjukkan nilai estimasi sebesar 0,015 dan nilai signifikansi 0,811 lebih besar dari 0,05 sehingga dapat disimpulkan bahwa variabel Pengakuan tidak berpengaruh signifikan terhadap Kualitas Komunikasi Dokter 
Lintangkerty Suryanagari, Tri Pitara Mahanggoro, Elsye Maria Rosa : Pengaruh Faktor Kepuasan Kerja terhadap Kualitas ....

Pasien yang berarti tidak sesuai dengan hipotesis ketiga (hipotesis 3 ditolak).

Pengujian hipotesis keempat menunjukkan bahwa pengaruh variabel Tanggung Jawab terhadap variabel Kualitas Komunikasi Dokter Pasien menunjukkan nilai estimasi sebesar -0,075 dan nilai signifikansi 0,265 lebih besar dari 0,05 sehingga dapat disimpulkan bahwa variabel Tanggung Jawab tidak berpengaruh signifikan terhadap Kualitas Komunikasi Dokter Pasien yang berarti tidak sesuai dengan hipotesis keempat (hipotesis 4 ditolak).

Hasil pengujian hipotesis kelima juga mengungkap bahwa variabel Promosi dan Pengembangan terhadap variabel Kualitas Komunikasi Dokter Pasien menunjukkan nilai estimasi sebesar 0,047 dan nilai signifikansi 0,374 lebih besar dari 0,05 sehingga dapat disimpulkan bahwa variabel Promosi dan Pengembangan tidak berpengaruh signifikan terhadap Kualitas Komunikasi Dokter Pasien yang berarti tidak sesuai dengan hipotesis kelima (hipotesis 5 ditolak).

\section{PEMBAHASAN}

Kelima variabel yang diuji terhadap kualitas komunikasi dokter-pasien merupakan faktor intrinsik kepuasan kerja yang disebut juga faktor motivasi. Tidak terdapat perngaruh antara 4 variabel dalam penelitian ini, sejalan dengan penelitian dengan subyek perawat yang dilakukan di PKU Muhammadiyah Yogyakarta, bahwa motivasi kerja perawat tidak ada korelasi dengan penerapan komunikasi terapeutik (Riyadi \& Yuniarti, 2016). Hasil ini juga dapat dikaitkan dengan hasil penelitian di Tanzania pada tahun 2006-2007 yang meneliti tingkat motivasi para klinisi, didapatkan hasil bahwa faktor motivasi yang tidak terkait dangan gaji hanya akan berpengaruh jika kebutuhan atas gaji terpenuhi, terutama pada klinisi yang berusia muda (Chandler dkk., 2009). Temuan tersebut bertolak belakang dengan penelitian yang dilakukan pada tenaga kesehatan yang bekerja di Jordania dan Georgia, bahwa intervensi non-keuangan yang mungkin lebih efektif untuk meningkatkan motivasi pekerja (Franco dkk., 2004).

Hasil analisis data variabel pekerjaan itu sendiri (work itself) bertolak belakang dengan variabel lainnya, disimpulkan pekerjaan itu sendiri (work itself) berpengaruh terhadap kualitas komunikasi dokter-pasien. Berdasarkan studi, konten pekerjaan merupakan determinan motivasi tenaga kesehatan yang bekerja di garda depan (Zarei dkk., 2016). Luaran kedokteran klinis dipengaruhi oleh sikap yang diadopsi oleh dokter ketika mencoba untuk membangun hubungan dengan pasien. Desain pekerjaan yang memelihara budaya kerja yang ramah dengan memenuhi kebutuhan psikologis yang 
mengatur faktor intrinsik memicu dokter memberikan komitmen kerja yang lebih baik (Nantha, 2013).

Studi ini memasukkan 3 item pertanyaan terkait pekerjaan itu sendiri atau work itself dalam kuesioner penelitian yaitu 'apakah Anda (dokter) menyukai pekerjaan Anda secara keseluruhan?', 'apakah tugas-tugas dalam pekerjaan Anda (dokter) bervariasi dan menarik?' dan 'apakah Anda (dokter) dapat memberikan manfaat yang penting dalam pekerjaan Anda?'. Tiga item tersebut merujuk pada pernyataan penelitian sebelumnya bahwa pekerjaan itu sendiri merujuk pada persepsi karyawan menyukai dan tidak menyukai pekerjaan, serta menurut studi sebelumnya juga bagi tenaga kesehatan yaitu perasaan bahwa pekerjaannya berguna bagi masyarakat (Bagheri dkk., 2013; Danish \& Usman, 2010). Hipostesis yang diterima sejalan dengan literatur yang menyatakan bahwa faktor psikologis berpengaruh dalam sebuah komunikasi (Sanusi, 2018). Penurunan keadaan afektif positif para dokter yang dikendalikan oleh motivasi intrinsic menyebabkan kualitas komunikasi dokter-pasien menjadi buruk (Nantha, 2013).

\section{SIMPULAN}

Pekerjaan itu sendiri (work itself) sebagai faktor intrinsik dari kepuasan kerja berpengaruh signifikan terhadap kualitas komunikasi dokter-pasien di puskesmas Kota Cirebon, sedangkan faktor-faktor intrinsk lain tidak bepengaruh. Penelitian ini hanya meneliti faktor intrinsik dari kepuasan kerja dokter sebagai variabel eksogen dan didapatkan bahwa faktor intrinsik tersebut hanya memiliki keterkaitan yang kecil sehingga saran untuk penelitian selanjutnya faktor-faktor ekstrinsik juga perlu dilakukan untuk mengetahui gambaran pengaruh faktor-faktor kepuasan kerja dokter terhadap komunikasi dokter-pasien lebih luas.

\section{UCAPAN TERIMA KASIH}

Ucapan terima kasih kepada seluruh civitas akademik program studi Magister Administrasi Rumah Sakit Universitas Muhammadiyah Yogyakarta, Dinas Kesehatan Kota Cirebon dan Puskesmas di Kota Cirebon.

\section{DAFTAR PUSTAKA}

Aziri, B. (2011). Job Satisfaction: A Literature Review. 3(4), 10.

Bagheri, S., Janati, A., Kousha, A., Adeghi-Bazargani, H., Asghari-Jafarabadi, M., \& Farahbakhsh, M. (2013). Job Satisfaction Differences between 
Lintangkerty Suryanagari, Tri Pitara Mahanggoro, Elsye Maria Rosa : Pengaruh Faktor Kepuasan Kerja terhadap Kualitas ....

Primary Health Care and Treatment Sectors: An Experience from Iran [Text/html]. Health Promotion Perspectives. https://doi.org/10.5681/HPP.2013.011

Bensing, J. M., Brink-Muinen, A. van den, Boerma, W., \& Dulmen, S. van. (2013). The manifestation of job satisfaction in doctor-patient communication: A ten-country European study. 14.

Bhatnagar, K., \& Srivastava, K. (2012). Job satisfaction in health-care organizations. Industrial Psychiatry Journal, 21(1), 75-78. https://doi.org/10.4103/0972-6748.110959

Chandler, C. I. R., Chonya, S., Mtei, F., Reyburn, H., \& Whitty, C. J. M. (2009). Motivation, money and respect: A mixed-method study of Tanzanian nonphysician clinicians. Social Science \& Medicine, 68(11), 2078-2088. https://doi.org/10.1016/j.socscimed.2009.03.007

Danish, R. Q., \& Usman, A. (2010). Impact of Reward and Recognition on Job Satisfaction and Motivation: An Empirical study from Pakistan. International Journal of Business and Management, 5(2), p159. https://doi.org/10.5539/ijbm.v5n2p159

Deriba, B. K., Sinke, S. O., Ereso, B. M., \& Badacho, A. S. (2017). Health professionals' job satisfaction and associated factors at public health centers in West Ethiopia. Human Resources for Health, 15(1). https://doi.org/10.1186/s12960-017-0206-3

Franco, L. M., Bennett, S., Kanfer, R., \& Stubblebine, P. (2004). Determinants and consequences of health worker motivation in hospitals in Jordan and Georgia. Social Science \& Medicine (1982), 58(2), 343-355. https://doi.org/10.1016/s0277-9536(03)00203-x

Giese, G., \& Avoseh, M. (2018). Herzberg's Theory of Motivation as a Predictor of Job Satisfaction: A Study of Non-academic Community College Employees. Excellence and Innovation in Learning and Teaching, 38-52. https://doi.org/10.3280/EXI2018-002003

HR, S. (2019). Statistik dan Metodologi Penelitian dengan Implementasi Pembelajaran Android. CV Karya Bakti Makmur. https://books.google.co.id/books?id=5HfEDwAAQBAJ

Konsil Kedokteran Indonesia. (2012). Standar Kompetensi Dokter Indonesia. Konsil Kedokteran Indonesia. http://www.kki.go.id/assets/data/arsip/SKDI_Perkonsil,_11_maret_13.pdf

Maharani, C. (2019). Primary care physicians' satisfaction after health care reform: A cross-sectional study from two cities in Central Java, Indonesia. 12.

Makoul, G., Krupat, E., \& Chang, C.-H. (2007). Measuring patient views of physician communication skills: Development and testing of the Communication Assessment Tool. Patient Education and Counseling, 67(3), 333-342. https://doi.org/10.1016/j.pec.2007.05.005

Mosadeghrad, A. M. (2014). Factors Influencing Healthcare Service Quality. International Journal of Health Policy and Management, 3(2), 77-89. https://doi.org/10.15171/ijhpm.2014.65 
Nantha, Y. S. (2013). Intrinsic motivation: How can it play a pivotal role in changing clinician behaviour? Journal of Health Organization and Management, 27(2), 266-272. https://doi.org/10.1108/14777261311321815

Riyadi, S., \& Yuniarti, Y. (2016). Hubungan Motivasi Kerja dan Lama Kerja Perawat dengan Penerapan Komunikasi Terapeutik pada Klien di Rumah Sakit PKU Muhammadiyah Kotagede Yogyakarta. Jurnal Kesehatan Karya Husada, 4(1), Article 1. http://jurnal.poltekkeskhjogja.ac.id/index.php/jkkh/article/view/392

Sanusi, A. (2018). Model Komunikasi Terapeutik dalam Pendidikan (Sebuah Pendekatan Terapeutik dalam Menangani Problematika Siswa). 17.

Scheepers, R. A., Boerebach, B. C. M., Arah, O. A., Heineman, M. J., \& Lombarts, K. M. J. M. H. (2015). A Systematic Review of the Impact of Physicians' Occupational Well-Being on the Quality of Patient Care. International Journal of Behavioral Medicine, 22(6), 683-698. https://doi.org/10.1007/s12529-015-9473-3

Shanafelt, T. D., Boone, S., Tan, L., Dyrbye, L. N., Sotile, W., Satele, D., West, C. P., Sloan, J., \& Oreskovich, M. R. (2012). Burnout and satisfaction with work-life balance among US physicians relative to the general US population. Archives of internal medicine, 172(18), 1377-1385.

Sharma, M., Goel, S., Singh, S. K., Sharma, R., \& Gupta, P. K. (2014). Determinants of Indian physicians' satisfaction \& dissatisfaction from their job. INDIAN J MED RES, 9.

van der Leeuw, R. M., Slootweg, I. A., Heineman, M. J., \& Lombarts, K. M. J. M. H. (2013). Explaining how faculty members act upon residents' feedback to improve their teaching performance. Medical Education, 47(11), 10891098. https://doi.org/10.1111/medu. 12257

Van Ham, I., Verhoeven, A. A. H., Groenier, K. H., Groothoff, J. W., \& De Haan, J. (2006). Job satisfaction among general practitioners: A systematic literature review. European Journal of General Practice, 12(4), 174-180. https://doi.org/10.1080/13814780600994376

World Health Organization, \& van Lerberghe, W. (2008). The World Health Report 2008: Primary Health Care: Now More Than Ever. World Health Organization. https://books.google.co.id/books?id=q-EGxRjrIo4C

Zarei, E., Najafi, M., Rajaee, R., \& Shamseddini, A. (2016). Determinants of job motivation among frontline employees at hospitals in Tehran. Electronic Physician, 8(4), 2249-2254. https://doi.org/10.19082/2249

\begin{tabular}{|l|l|}
\hline Submission & $16-05-2021$ \\
\hline Review & $21-06-2021$ \\
\hline Accepted & $25-09-2021$ \\
\hline Publish & $29-10-2021$ \\
\hline DOI & $10.29241 /$ jmk.v7i2.622 \\
\hline Sinta Level & 3 (Tiga) \\
\hline
\end{tabular}

